\title{
Morphological characteristics and flavonoid accumulation of Echinacea purpurea cultivated at various salinity
}

\author{
JESSYCA PUTRI CHOIRUNNISA ${ }^{1, \vartheta}$, YULI WIDIYASTUTI ${ }^{2}$, AMALIA TETRANI SAKYA ${ }^{3}$, AHMAD YUNUS ${ }^{3,4, v \vee}$ \\ ${ }^{1}$ Graduate School of Agronomy, Faculty of Agriculture, Universitas Sebelas Maret. Jl. Ir. Sutami 36A, Kentingan, Surakarta, 57126, Central Java, \\ Indonesia. Tel./fax.+62-271-637457, `email: jessycaputri6@gmail.com \\ ${ }^{2}$ Research and Development Center for Medicinal Plant and Traditional Medicines. Jl. Raya Lawu No. 11, Tawangmangu, Karanganyar 57792, Central \\ Java, Indonesia \\ ${ }^{3}$ Department of Agrotechnology, Faculty of Agriculture, Universitas Sebelas Maret. Jl. Ir. Sutami 36 A, Surakarta 57126, Central Java, Indonesia. \\ Tel./fax. +62-271-637457, ^vemail: yunus.uns7@yahoo.com \\ ${ }^{4}$ Center of Biotechnology and Biodiversity, Research and Development, Universitas Sebelas Maret. J1. Ir. Sutami 36A, Kentingan, Surakarta 57126, \\ Central Java, Indonesia
}

Manuscript received: 28 July 2021. Revision accepted: 15 August 2021

\begin{abstract}
Choirunnisa JP, Widiyastuti Y, Sakya AT, Yunus A. 2021. Morphological characteristics and flavonoid accumulation of Echinacea purpurea cultivated at various salinity. Biodiversitas 22: 3716-3721. Purple coneflower (Echinacea purpurea (L.) Moench) is an introduced medicinal plant from North America. E. purpurea has high morphological characteristics on stems, leaves and flowers. This plant has not much cultivated as a raw material for traditional medicine in Indonesia due to not much information about flavonoid accumulation of E. purpurea in this country. The purpose of this research was to study morphological characteristics from three accessions of E. purpurea cultivated with various salinity and to select $E$. purpurea accessions that have high flavonoid accumulation. This study design using a factorial Completely Randomized Design (CRD). The first factor is 3 accessions of E. purpurea (E1; E2; E3). The second factor is 4 levels of $\mathrm{CaCl}_{2}(0 \mathrm{ppm} ; 2500 \mathrm{ppm} ; 5000 \mathrm{ppm} ; 10000 \mathrm{ppm})$. The study was conducted by observing the morphological characteristics of stems, leaves flowers, and herb extract and flavonoid accumulation were analyzed using SPSS. The results demonstrated that morphological characteristics are easy to observed on leaf shape and flower color. The highest herb extract with $10.043 \%$ and flavonoid accumulation with $0.510 \%$ were in accession 2 with the addition of $\mathrm{CaCl}_{2}$ concentration of $10000 \mathrm{ppm}$. This study concludes that there are morphological characteristics of E. purpurea cultivated at various salinity and the highest $\mathrm{CaCl}_{2}$ concentration can increase with significance to herb extract and flavonoid accumulation.
\end{abstract}

Keywords: Accession, $\mathrm{CaCl}_{2}$, characteristics, Echinacea purpurea, flavonoid

\section{INTRODUCTION}

Echinacea purpurea (L.) Moench or purple coneflower is a medicinal plant from North America introduced in Indonesia. E. purpurea began to be studied in Indonesia in 1998 , the results showed that E. purpurea is well grown to altitude range 450-1100 meters above sea level (m asl) in the tropics (Rahardjo 2000). E. purpurea cultivated in Indonesia has many morphological changes due to different climate conditions from North America. Indonesia has tropical climate characterized by high and longer rainfall, and frequent high temperatures (Center for Research and Development 2010). North America has subtropical climate characterized by full sun exposure and low temperatures (Mangini and Areta 2018). Kindscher (2016) stated that E. purpurea cultivated in Canada has risen red and dark purple flower colors, while Sidhiq et al. (2020) obtained flower color variations including pale pink, dark pink, and dark purple on E. purpurea in Karangpandan, Central Java, Indonesia. Morphological differences are influenced by environmental factors, genetics, and interaction between two factors (Benito et al. 2016). Morphological characteristics are currently used in plant classification and classified as the fastest method for preparation of plant diversity. Morphological characters are more easily recognized and simple to observe than other plant characters (Landey et al 2013).

Traditional medicine production from 2018 to 2019 increased by $18.58 \%$ (Central Bureau of Statistics 2020). The increasing health costs and many disease outbreaks attack the human body, causing medicinal plants as raw materials for traditional medicines to increase (Sofowora et al. 2019). E. purpurea is useful as an antioxidant, antiinflammatory, and immunomodulator, and has no hypersensitivity in clinical trials (Sidhiq et al. 2020). Flavonoids are secondary metabolites from phenolic compound derivatives are the dominant compounds in $E$. purpurea (Kurkin et al. 2011). Flavonoid compounds indicate antioxidant and immunomodulatory effects by boosting the immune system (Khazdair et al. 2018). The adaption of $E$. purpurea cultivated in Indonesia has a promising opportunity to develop as a raw material for traditional medicine. Nonetheless, E. purpurea as an introduced plant has not much research in Indonesia about the diversity of $E$. purpurea with maximizing flavonoid accumulation.

The flavonoid accumulation can be increased by abiotic stress such as stress salinity by $\mathrm{CaCl}_{2}$. Khorasaninejad et al. (2020) stated that stress salinity can increase the flavonoid accumulation by $90 \%$ in E. purpurea. Research results in 
other Asteraceae species by Madany and Khalil (2017), sunflower plants with $5 \mathrm{mM} \mathrm{CaCl} \mathrm{Cl}_{2}$ treatment can increase the flavonoid accumulation with $0.1 \mathrm{mg}$ This study aims to determine the morphological variations and flavonoid accumulation in three accessions of E. purpurea and to determine plants having good potential to be developed based on the flavonoid accumulation.

\section{MATERIALS AND METHODS}

\section{Experimental design}

This study used a factorial Completely Randomized Design (CRD) method. The first factor was accession (E) consisted of 3 levels (E1; E2; E3). The second factor was $\mathrm{CaCl}_{2}$ concentration consisted of 4 levels, namely $0 \mathrm{ppm}$ (C1), 2500 ppm (C2), 5000 ppm (C3), and 10000 ppm (C4), so it had 12 treatment combinations. E. purpurea was planted at the Jumantono Experimental Field, Sebelas Maret University, Karanganyar, Central Java, Indonesia (293 m asl) in December 2020 to June 2021.

\section{Field experimental procedure}

Accession selection

Three accessions of E. purpurea were obtained from mass selection from the Center for Research and Development of Medicinal Plants and Traditional Medicines (B2P2TOOT), Tawangmangu, Indonesia. E. purpurea accessions were selected from identifying morphological differences by covering leaf shape, flower shape, flower color and stem color.

\section{Application of $\mathrm{CaCl}_{2}$}

$\mathrm{CaCl}_{2}$ solution was applied 4 times in the plant vegetative phase, namely on plants aged 4 WAP (Week After Planting), 5 WAP, 6 WAP, and 7 WAP with watering intervals of once a week. Watering volume according to treatment concentration determined by field capacity.

\section{Morphological identification}

Identification of morphological characters in E.purpurea accession used descriptive non-experimental method and observed directly. The observed variables included morphological characters of stem color, stem surface texture, leaf shape, leaf margin, leaf tip, upper leaf surface texture, lower leaf surface texture, leaf color, flower shape, flower edge shape, flower petals tip shape, flower edge density, flower color, and flower bud color.

\section{Analysis of herb extract}

Extract of E. purpurea taken from all plant parts (stems, leaves, flowers, and roots) that have been harvested and dried for 7 days at room temperature then dried again with oven at $50^{\circ} \mathrm{C}$ temperature. The dried herbs were ground into powder and weighed $5 \mathrm{~g}$ as the initial sample weight. The $5 \mathrm{~g}$ powder sample was put in a bottle by adding $50 \mathrm{ml}$ of $70 \%$ ethanol and macerated for 3 days, then filtered and placed in a cup that had previously weighed as initial weight of the cup then dried. The dried extract was weighed as a final weight of the cup and calculated weight of the herbal extract by subtracting the cup's initial weight from the cup's final weight (Center for Research and Development of Medicinal Plants and Traditional Medicines 2018). The herb extract of E. purpurea was calculated using the formula:

$$
r(\%)=\frac{x}{y} \times 100
$$

Where:

$r$ : Herb extract content $(\%)$

$\mathrm{x}:$ Herbal extract weight $(\mathrm{g})$

$\mathrm{y}:$ Initial sample weigh $(\mathrm{g})$

\section{Analysis of flavonoid}

Analysis of the flavonoid accumulation was performed using the Aluminum chloride colorimetric method from Chang et al. (2002) with slight modification. The thick extract was weighed $100 \mathrm{mg}$ and dissolved with $70 \%$ ethanol to a volume of $10 \mathrm{ml}$, then sonicated for 15 minutes and deposited overnight. The extract was taken $4 \mathrm{ml}$ and put in oven at $50^{\circ} \mathrm{C}$ temperature, then dissolved with $8 \mathrm{ml}$ methanol, after that sonicated for 15 minutes and deposited overnight. Make 2 solutions for flavonoid testing by adding $0.2 \mathrm{ml}$ extract solution and $4.8 \mathrm{ml}$ aquabidest as the first sample solution, make second sample solution by adding $0.2 \mathrm{ml}$ extract solution, $1 \mathrm{ml} \mathrm{AlCl} 3$ and $3.8 \mathrm{ml}$ aquabidest, then each sample solution was incubated for 15 minutes. The first sample solution was read at the maximum wavelength using UV-VIS Spectrophotometer at 370-450 $\mathrm{nm}$ wavelength, determine operating time with reading the most stable absorbance value at $415 \mathrm{~nm}$ wavelength then make a standard curve by pipetting $2 \mathrm{ml}$ second sample solution. After that reading absorbance value at the maximum wavelength and operating time obtained from the first sample solution. The quercetin concentration was calculated by the curve equation of $y=0.0383 x+0.0911$, $y$ value is absorbance of curve standard and $\mathrm{x}$ value is concentration of quercetin $(\mathrm{mg} / \mathrm{L})$. Flavonoid accumulation in the extract was calculated using the formula:

$$
\mathrm{F}=\frac{\mathrm{C} \times \mathrm{V} \times \mathrm{FP} \times 10^{-3}}{\mathrm{M}} \times 100
$$

Where:

F : Flavonoid accumulation (\%)

$\mathrm{C}:$ Quercetin concentration $(\mathrm{mg} / \mathrm{L})$

$\mathrm{V}$ : Extract volume (L)

FP : Dilution factor

M : Sample weight (mg)

\section{Data analysis}

Qualitative data of morphological characteristics were analyzed descriptively and quantitative data of herb extract and flavonoid accumulation were analyzed by Analysis of Variance (ANOVA), simple correlation analysis, and Duncan Multiple Range Test (DMRT) level of 5\% using SPSS (Statistical Product and Service Solution) 21.0. 


\section{RESULTS AND DISCUSSION}

Morphological variations in stems, leaves, and flowers occur in $60 \mathrm{E}$. purpurea plants cultivated at various salinity levels. Almost $70 \%$ variation occurs in the morphology of leaves and flowers. In accordance with Subositi and Fauzi (2012), there are 8 accessions of E. purpurea that have morphological variants, especially in leaf and flower morphology. Salinity stress by $\mathrm{CaCl}_{2}$ can increase herb extract by more than $24 \%$ and flavonoid accumulation by more than $29 \%$. Sarker and Oba (2018) stated that salinity stress can increase the production of secondary metabolites such as phenolic compounds and flavonoids in plants.

\section{Morphological characters of $\boldsymbol{E}$. purpurea Stem}

Morphological variations occur almost $30 \%$ in stems of E. purpurea. Morphological variations in stems can be easily observed based on stem color and stem surface texture. Accession 1 has a light green stem color with dark green and white spots. Accession 2 has a yellowish-green stem color with purple spots. Accession 3 has a dark green stem color with brownish-red spots (Figure 1). The stem surface texture of accession 1has a slightly rough, while accession 2 and accession 3 had a rough stem surface texture. Banga and Ardelean (2008) stated that 7 accessions of E. purpurea collected in Cluj Napoca Romania had morphological diversity in stems. The accessions in the study were different from their previous parents. This was thought to be propagated using seeds so as to produce new variants that were different from the parent. Subositi and Fauzi (2016) reported that new morphological variants are caused by mass selection using seeds, resulting in some offspring having morphological differences with their parents. This is in accordance with the statement of Baum et al. (1999) that genetic variability in E. purpurea causes of generative propagation. Mass selection using seeds causing differences of morphological from 4 species $E$. purpurea (Yavari et al. 2017).

\section{Leaf}

Leaf morphology of 3 accessions $E$. purpurea grown at various concentrations of $\mathrm{CaCl}_{2}$ had almost $60 \%$ variation in leaf shape (Figure 2). Accession 1 has an oblong leaf shape that is elongated with a wavy tapered leaf tip. Accession 2 has an oval leaf shape and extending towards the base (lanceolate) with a tapered leaf tip, while leaf shape of accession 3 is widened to the center (ellipse) with a blunt leaf tip. Accession 1 and accession 2 had the same leaf margin, which is jagged grooves, while the leaf margin of accession 3 is flat and serrated. Accession 2 has the smoothest upper leaf surface texture and the lower leaf surface texture is sparse and rough-haired. Accession 1 and accession 3 had the same leaf surface texture of upper and lower which is rough. Accession 2 has a green leaf color as the brightest leaf color. The color leaf of accession 1 and accession 3 is dark green. Pop (2010) stated that 10 accessions of E. purpurea produced morphological variations in leaves, such as leaf shape, leaf length, and leaf width. The different leaf morphology of E. purpurea from its parents is caused by environmental factors. Humidity, temperature, and stress are environmental factors that can affect the metabolism of plant and causing morphology differences in plant (Sidhiq et al. 2020), such as the change of leaf shape. According to Lin-na (2013), the differences in morphological characters of 14 accessions E. purpurea were easily affected by growth environmental factors such as temperature and sunlight. Color changes in plant morphology are caused by lack of nutrients, water, or sunlight due to environmental stress (Pratiwi et al. 2019). According to Varban et al. (2010), plants have different adaptation levels for environmental changes that synergize with genetic factors. E. purpurea has a different leaf morphology in leaf shape and color shape caused the different tolerance levels between accessions of $E$. purpurea to changes in environmental conditions.

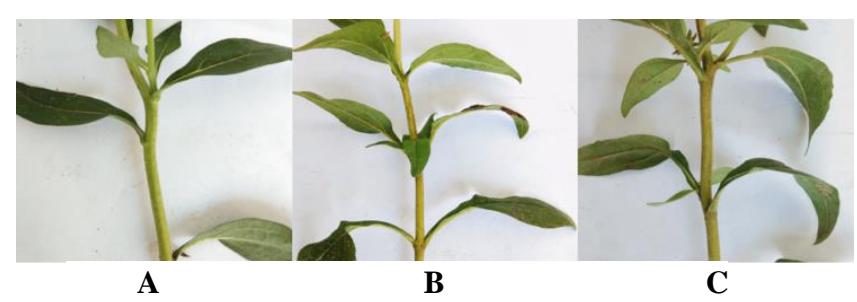

Figure 1. Stem morphology of three E. purpurea: A. Accession 1, B. Accession 2, C. Accession 3

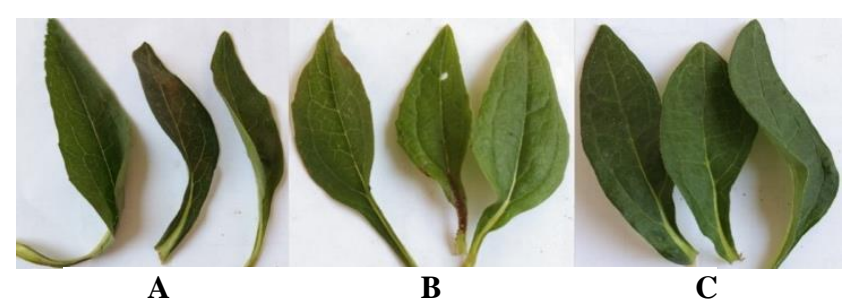

Figure 2. Leaf morphology of three E. purpurea: A. Accession 1, B. Accession 2, C. Accession 3

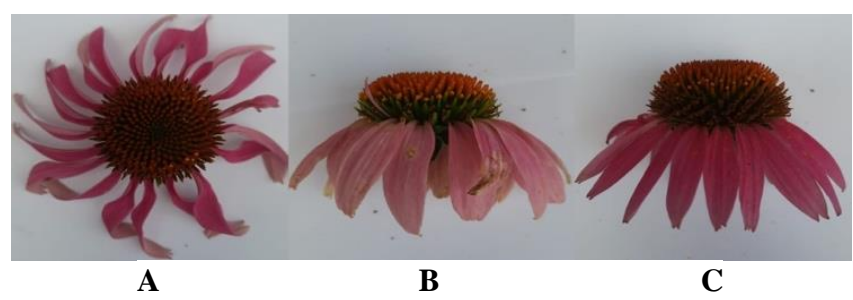

Figure 3. Flower morphology of three E. purpurea: A. Accession 1, B. Accession 2, C. Accession 3

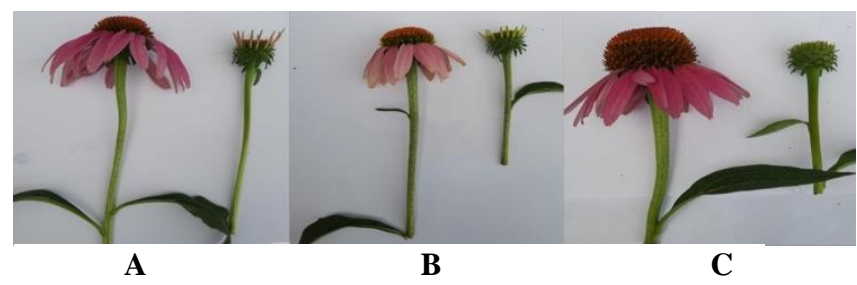

Figure 4. The morphology of color leaf and color shoots in three E. purpurea: A. Accession 1, B. Accession 2, C. Accession 3 


\section{Flower}

Flowers have the most striking morphological differences and are easily visually observed. The diversity of flower morphology can easily be observed in the flower shape (Figure 3), accession 1 has a flat flower shape, while accession 2 and accession 3 have a downward curving flower shape. Accession 1 and accession 3 have the same flower edge shape which is elongated oval, while flower edge shape of accession 2 is lanceolate. Accession 3 has the flower petals tip is shaped like the letter $\mathrm{V}$ with 1 indentation. The flower petals tip of accession 1 and accession 2 are shaped like the letter $\mathrm{W}$ with 2 indentations. Accession 2 has the densest flower edge density and flower edges each other support and accession 3 has flower edge density is tight but not mutually supportive between flower edges, widely accession 1 has flower edge density that rarely or not overly tight. The diversity of flower color is also easy to observe, accession 2 has the most different flower color with accession 1 and accession 3 . Accession 2 has a pale pink flower color with yellowish-green flower bud color. Accession 1 has a purplish-pink flower color with the flower bud color is pink green and accession 3 has dark-pink flower colors with light green flower bud color (Figure 4). Almost $70 \%$ of flower shapes and colors differ from their parents due to self-incompatibility in $E$. purpurea. The diversity of agronomic and morphological in $E$. purpurea species is caused by cross-pollination with generating $E$. purpurea seeds with different morphology from the parent (Sidhiq et al. 2020). E. purpurea is a plant with self-incompatibility that can cause a high diversity in plant morphology (Subositi and Widyastuti 2013). According to Kang et al. (2015), the cross of hibiscus (Hibiscus rosasinensis) flower using intraspecific hybridization method can produce the difference of flower shape, flower size, and flower color.

\section{Herb extract}

The results of the herb extract analysis are presented in Figure 5. Based on data analysis, there was no interaction between accession and addition of $\mathrm{CaCl}_{2}$ concentration to herb extract. The highest herb extract was obtained by accession 2 in the concentration of $10000 \mathrm{ppm} \mathrm{CaCl}_{2}$ with a value of $10.043 \%$, significantly different from accessions 1 and 3 . The concentration of $10000 \mathrm{ppm} \mathrm{CaCl}_{2}$ can increase the herb extract of accession 1 with a value of $30.88 \%$, then in the herb extract of accession 2 with a value of $23.80 \%$, and the herb extract of accession 3 with a value of $27.62 \%$.

The higher $\mathrm{CaCl}_{2}$ concentration has resulted in the highest extract of E. purpurea herb (Figure 5), due to can cause plant stress and can affect the production of active compounds in herb extract. According to research Amallia et al. (2020), the highest extract of Centella asiatica herb with a value of $13.80 \%$ was found in salt content of 3000 $\mathrm{ppm}$, due to increased production of active compounds in the herb extract as a response of plants to stress conditions. The high herb extract indicates many active compounds in plant extracts, according to statement of Zohra and Fawzia (2014) that active compounds content in plants is related to value of herb extract. The higher of herb extract, the more active compounds are attracted to the solvent (Quispe et al. 2017).

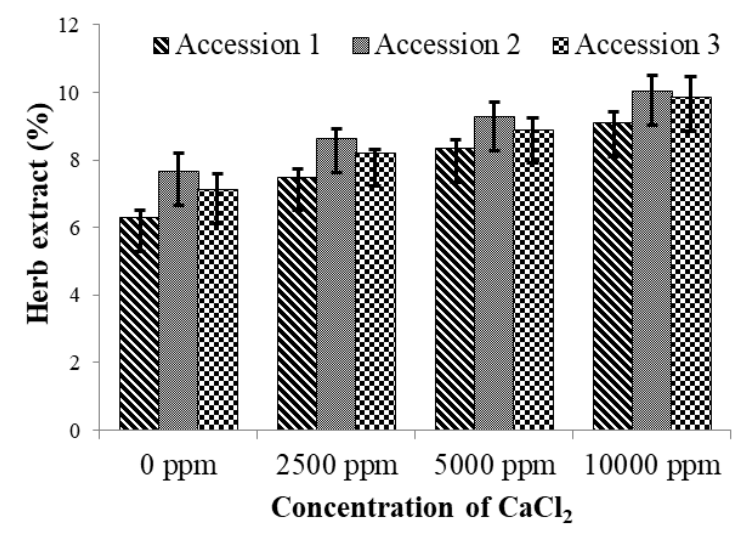

Figure 5. Herb extract of three E. purpurea accessions at various $\mathrm{CaCl}_{2}$ concentrations

Table 1. Flavonoid accumulation of three E. purpurea accessions that resulted at various $\mathrm{CaCl}_{2}$ concentrations

\begin{tabular}{ccccc}
\hline \multirow{2}{*}{ Accessions } & \multicolumn{4}{c}{$\mathbf{C a C l}_{\mathbf{2}}$ concentrations } \\
\cline { 2 - 5 } & $\mathbf{0 ~ p p m}$ & $\begin{array}{c}\mathbf{2 5 0 0} \\
\mathbf{p p m}\end{array}$ & $\begin{array}{c}\mathbf{5 0 0 0} \\
\mathbf{p p m}\end{array}$ & $\begin{array}{c}\mathbf{1 0 0 0 0} \\
\mathbf{p p m}\end{array}$ \\
\hline 1 & $0.267 \mathrm{a}$ & $0.313 \mathrm{ab}$ & $0.367 \mathrm{~b}$ & $0.428 \mathrm{~d}$ \\
2 & $0.356 \mathrm{~b}$ & $0.408 \mathrm{c}$ & $0.459 \mathrm{e}$ & $0.510 \mathrm{~g}$ \\
3 & $0.308 \mathrm{ab}$ & $0.361 \mathrm{~b}$ & $0.420 \mathrm{~d}$ & $0.469 \mathrm{f}$ \\
\hline
\end{tabular}

Note: Numbers followed by different lowercase letters in each column indicate a significant difference in DMRT level of 5\%

Tabel 2. Correlation analysis between variables

\begin{tabular}{lc}
\hline Variables & Flavonoid accumulation \\
\hline Accessions & $1.000^{* *}$ \\
CaCl2 concentrations & $0.484^{* *}$ \\
Herb extract & $0.982^{*}$
\end{tabular}

Note: The sign $* *$ indicates very significant difference in simple correlation analysis level of $5 \%$

\section{Accumulation of flavonoid}

Flavonoids are secondary metabolites colored yellow from a group of phenolic compound. Flavonoids have three physiological functions for plants, including as color pigments (anthocyanins), protection to high UV radiation (flavonols and flavones), and acting as plant defense signals in stress conditions (isoflavones) (Pambudi et al. 2014). Flavonoid pigments are also useful in humans as immunomodulators and antioxidants (Heldt and Piechulla 2011). The results of analysis of flavonoid accumulation are presented in Table 1. Based on data analysis, there was an interaction between accession and addition of $\mathrm{CaCl}_{2}$ concentration to flavonoid accumulation. Accession 2 with the treatment of $10000 \mathrm{ppm} \mathrm{CaCl}_{2}$ concentration had the highest flavonoid accumulation with a value of $0.510 \%$, while accession 1 without the addition of $\mathrm{CaCl}_{2}$ resulted in the lowest flavonoid accumulation with a value of $0.267 \%$. The accumulation of flavonoids in accession 2 was significantly different at various concentrations of $\mathrm{CaCl}_{2}$. The response of each accession in the confront of salt stress 
showed different results in the accumulation of flavonoids, accession 2 showed a better response than accessions 1 and 3. In addition to environmental factors, variations in morphology and content of secondary metabolites in plants are caused by genetic factors in each accession (Yang et al. 2016).

The higher $\mathrm{CaCl}_{2}$ concentration can increase the flavonoid accumulation in all accessions of $E$. purpurea (Table 1). This is caused by the high concentration of $\mathrm{CaCl}_{2}$ causing plant stress, so that plants will respond in the form of osmoregulation which involves osmotic regulation in the confronts of salt stress. Kaouther et al. (2013) stated that osmoregulation in saline-stressed plants would involve synthesizing organic acid compounds and amino acids to increase turgor pressure and decrease cell osmotic potential. Synthesis of amino acid compounds can increase the activity of the PAL (Phenylalanine Ammonia-Lyase) enzyme as an important compound in flavonoid biosynthesis through the pathway of phenylpropanoid. According to Valifard et al. (2015) salinity stress can synthesize the amino acid L-phenylalanine to produce PAL enzymes. The biosynthesis of phenolic compound groups of flavonoids requires a PAL enzyme as a precursor in the phenylpropanoid pathway (Zhang et al. 2021). Wang et al. (2021) reported that 5 mmol-L-1 $\mathrm{CaCl}_{2}$ increased $25 \%$ PAL enzyme activity and $18 \%$ flavonoid accumulation in dwarf saltwort (Salicornia bigelovii Torr) plants.

Based on Table 2, we showed that the flavonoid content is positively correlated with accession $2, \mathrm{CaCl}_{2}$ concentration and herb extract. The higher concentration of $\mathrm{CaCl}_{2}$ in $E$. purpurea can produce bioactive compounds in the herb extract, affecting the higher accumulation of flavonoids. Aghdam et al. (2013) stated that salt stress using $\mathrm{CaCl}_{2}$ can be used to increase the production of secondary metabolites in the form of flavonoids. The results of Chakraborty et al. (2015) stated that the $\mathrm{CaCl}_{2}$ concentration of $5 \mathrm{mM}$ can increase $40 \%$ of total flavonoids in tomato plants. Khorasaninejad et al. (2020) stated that $50 \mathrm{mM}$ salinity increased $72 \%$ of the flavonoid content in E. purpurea.

The high salt content causes an increase in the number of bioactive compounds (Kamiab et al. 2012). Herb extract value is related to the number of bioactive compounds, the higher the number of bioactive compounds (Altemimi et al. 2017). Syafitri et al. (2014) stated that the herb extract of Harendong ripe fruit was $50.89 \%$ indicating the highest total flavonoid content $(105.93 \mathrm{mg} / \mathrm{g})$, while the lowest total flavonoid content was found in the slight amount of extract $(42.08 \%)$.

The results of this study concluded that the morphological variations of three E. purpurea accessions cultivated under various salinity stresses could be distinguished based on the morphology of stems, leaves and flowers descriptively. Morphological variations are were found in stem color, flower color, leaf shape and flower shape. $\mathrm{CaCl}_{2}$ concentration of $10000 \mathrm{ppm}$ increased 24-31\% herb extract and 29-38\% flavonoid accumulation in three accessions of E. purpurea. Accession 2 had the highest herb extract and the highest accumulation of flavonoids, so that it showed characteristics of more tolerance to salinity stress than accession 1 and accession 3 .

\section{ACKNOWLEDGEMENTS}

The authors would like to thank the Center for Research and Development of Medicinal Plants and Traditional Medicines (B2P2TOOT), Tawangmangu, Indonesia for supporting on preparation of E. purpurea seeds and access for analysis in the laboratory, as well as to the Ministry of Research, Technology and Higher Education for the financial assistance provided.

\section{REFERENCES}

Aghdam MS, Dokhanieh AY, Hassanpour H, Fard JR. 2013. Enhancement of antioxidant capacity of Cornelian Cherry (Cornus mas) fruit by postharvest calcium treatment. Sci Hortic 161: 160-164. DOI: 10.1016/j.scienta.2013.07.006

Altemimi A, Lakhssassi N, Baharlouei A, Watson DG, Lightfoot DA. 2017. Phytochemicals: extraction, isolation, and identification of bioactive compounds from plant extracts. Plants 6(42): 1-23. DOI: 10.3390/plants6040042

Amallia N, Mas'ud ZA, Ratnadewi D. 2020. Production of secondary metabolites of gotu kola (Centella asiatica) plant in conditions of salinity stress and drought. Jurnal Ilmu Indonesia 5 (2): 68-75. [Indonesian]

Banga D, Ardelean M. 2008. Phenotypical variability of some Echinacea genus characters. Proceedings of 43rd Croatian and 3rd International Symposium on Agriculture. Opatija, Croatia.

Baum BR, Binns SE, Mechanda S, Arnason JT. 1999. The Echinacea germplasm enhancement project. Proceedings of The 1999 International Echinacea Symposium, Jun 3-5, Kansas City, MO.

Benito A, Hervella L, Tabernero J, Pennos A, Ginis H, Sánchez-Romera JF, Ordoñana JR, Ruiz-Sánchez M, Marín JM, Artal P. 2016. Environmental and genetic factors explain differences in intraocular scattering. Vis Psychophys Physiol Opt 57 (1): 163-168. DOI: 10.1167/iovs.15-17897

Center for Research and Development. 2010. Climate of the Indonesian Region.http://puslitbang.bmkg.go.if/litbang/wpcontent/uploads/2018/ 01/ikli,-kawasan-indonesia.pdf [Indonesia]

Center for Research and Development of Medicinal Plants and Traditional Medicines (B2P2TOOT). 2018. Analysis of Flavonoid. Instrument Laboratory Procedure B2P2TOOT. Research and Development Center for Medicinal Plant and Traditional Medicines, Tawangmangu, Karanganyar. [Indonesian]

Central Bureau of Statistics (BPS). 2020. IBS production growth in 2019 up $4.01 \%$ compared to 2018. https://www.bps.go.id/pressrelease/2020/02/03/1739/pertumbuhanproduksi-ibs-tahun-2019-naik-4-01-persen-dibandingkan-tahun2018.html. [Indonesian]

Chakraborty N, Chandra S, Acharya K. 2015. Sublethal heavy metal stress stimulates innate immunity in Tomato. The Sci World J 2015: 208649. DOI: 10.1155/2015/208649

Chang CC, Yang MH, Wen HM, Chern JC. 2002. Estimation of total flavonoid content in propolis by two complementary colorimetric methods. J Food Drug Anal 10 (3): 178-182. DOI: 10.38212/22246614.2748

Heldt HW, Piechulla B. 2011. Plant Biochemistry. Four Edition. Academic Press Elsevier, London.

Kamiab F, Talaie A, Javanshah A, Khezri M, Khalighi A. 2012. Effect of long-term salinity on growth, chemical composition and mineral elements of Pistachio (Pistacia vera cv. Badami-Zarand) rootstock seedlings. Ann Biol Res 3 (12): 5545-5551.

Kang HC, Ha YM, Kim KH. 2015. A new hibiscus cultivar 'Woolred' with vigorous growth and unique flower shape through interspesific hybridization. Flower Res J 23 (4): 276-280. DOI: 10.11623/frj.2015.23.4.45 
Kaouther Z, Nina H, Rezwan A, Cherif H. 2013. Evaluation of salt tolerance $(\mathrm{NaCl})$ in Tunisian chili pepper (Capsicum frutescens $\mathrm{L}$.) on growth, mineral analysis and solutes synthesis. J Stress PhysioL Biochem 9(1): 209-228.

Khazdair MR, Ghorani V, Alavinezhad A, Boskabady MH. 2018 Pharmacological effects of Zataria multiflora Boiss L. and its constituents focus on their anti-inflammatory, antioxidant, and immunomodulatory effects. Fundam Clin Pharm 32(1): 26-50. DOI: $10.1111 /$ fcp. 12331

Khorasaninejad S, Zare F, Hemmati K. 2020. Effects of silicon on some phytochemical traits of Purple Coneflower (Echinacea purpurea L.) under salinity. Sci Hortic 264: 1-6. DOI: 10.1016/j.scienta.2019.108954

Kindscher K. 2016. The biology and ecology of Echinacea Species. In: Kindscher K. (eds). The Conservation Status of Echinacea Species. Springer, Cham

Kurkin VA, Akushskaya AS, Avdeeva EV, Velmyaikina EL, Daeva ED, Kadentsev VL. 2011. Flavonoids from Echinacea purpurea. Russian J Bioorgan Chem 37 (7): 905-906. DOI 10.1134/S1068162011070120.

Landey RB, Cenci A, Georget F, Bertrand B, Camayo G, DechampE, Herrera JC, Santoni S, Lashermes P, Simpson J, Etienne H. 2013 High genetic and epigenetic stability in Coffea arabica plants derived from embryogenic suspensions and secondary embryogenesis as revealed by AFLP, MSAP and the phenotypic variation rate. Plos One 8(2): 1-15. DOI: $10.1371 /$ journal.pone.0056372.

Lin-na H. 2013. The morphological markers of different phenotypes Echinacea purpurea. J Appl Pharm Sci 3 (9): 078-080. DOI: 10.7324/JAPS.2013.3914.

Madany MMY, Khalil RR. 2017. Seed priming with ascorbic acid or calcium chloride mitigates the adverse effects of drought stress in Sunflower (Helianthus annuus L.) seedlings. Egypt J Exp Biol (Bot) 13 (1): 119-133. DOI: 10.5455/egyjebb.20170409090612.

Mangini GG, Areta JI. 2018. Bird mixed-species flok formation is driven by low temperatures between and within seasons in a Subtropical Andean-foothill forest. Biotropica 0(0):1-10. DOI: 10.1111/btp.12551

Pambudi A, Syaefudin, Noriko N, Swandari R, Azura PR. 2014 Identification of the bioactive flavonoid group of Earring (Acalypha indica L.) plants. Jurnal Al-Azhar Indonesia Seri Sains dan Teknologi 2(3): 178-187. DOI: 10.36722/sst.v2i3.139. [Indonesian]

Pop MR. 2010. Characters with multiple usages-phenotypic variability analysis at Echinacea purpurea (L.) Moench Species. Analele Universității din Oradea-Fascicula Biol Tom 17 (2): 329-331.

Pratiwi E. 2010. Comparison of Maceration, Remaceration, Percolation and Repercolation Methods in Extraction of Active Andrographolide Compounds from Sambiloto (Andrographis paniculata Nee) Plants. [Thesis]. Faculty of Agricultural Technology. IPB, Bogor. [Indonesian]

Pratiwi PY, Mardiyaningsih A, Widarti E. 2019. Quality differences of Mint (Mentha spicata L) plant hydroponic and conventional based on plant morphology, chromatogram profile, and essential oil content. Jurnal Riset Kefarmasian Indonesia 1 (2): 148-156. DOI : 10.33759/jrki.v1i2.18. [Indonesian]

Quispe YNG, Hwang SH, Wang Z, Zuo G, Lim SS. 2017. Screening in vitro targets related to diabetes in herbal extracts from Peru identification of active compounds in Hypericum laricifolium Juss. by offline high-performance liquid chromatography. Int J Mol Sci 18: 117. DOI: $10.3390 / \mathrm{ijm} s 18122512$.
Rahardjo M. 2000. Echinacea: Potential introduced drug plants. Warta Penelitian dan Pengembangan Tanaman Industri 6 (2): 1-3. [Indonesian]

Sarker U, Oba S. 2018. Augmentation of leaf color parameters, pigments, vitamins, phenolic acids, favonoids and antioxidant activity in selected Amaranthus tricolor under salinity stress. Sci Rep 8: 1-9. DOI: 10.1038/s41598-018-30897-6

Sidhiq DF, Widiyastuti Y, Subositi D, Pujiasmanto B, Yunus A. 2020. Morphological diversity, total phenolic and flavonoid content of Echinacea purpurea cultivated in Karangpandan, Central Java, Indonesia. Biodiversitas 21 (3): 1265-1271. DOI: 10.13057/biodiv/d210355.

Sofowora A, Ogunbodede E, Onayade A. 2013. The role and place of medicinal plants in the strategies for disease prevention. Afr J Tradit Compl Altern Med 10(5): 210-219. DOI: 10.4314/ajtcam.v10i5.2.

Subositi D, Fauzi. 2012. Morphological variation of ekinase (Echinacea purpurea (L.) Moench) accessions from mass selection year I on Medicinal Plant and Traditional Medicine Research and Development office (B2P2TOOT). Jurnal Tumbuhan Obat Indonesia 5 (2): 123129. [Indonesian]

Subositi D, Fauzi. 2016. Intraspecific diversity of accession Ekinase (Echinacea purpurea (L.) Moench) phase I mass selection results based on ISSR analysis. Indon J Plant Med 9 (1): 11-18. [Indonesian]

Subositi D, Widiyastuti Y. 2013. Genetic diversity of accession of ekinase (Echinacea purpurea (L.) Moench) from the results of year 1 mass selection through RAPD analysis. Bul Kebun Raya 16 (2): 93-100. DOI: 10.14203/bkr.v16i2.33. [Indonesia]

Syafitri NE, Bintang M, Falah S. 2014. Phytochemical content, total phenol, and total flavonoid Harendong (Melastoma affine D. Don) fruit extract. Curr Biochem 1 (3): 105-115. DOI: $10.29244 / \%$ p. [Indonesian]

Valifard M, Mohsenzadeh S, Niazi A, Moghadam A. 2015. Phenylalanine ammonia lyase isolation and functional analysis of phenylpropanoid pathway under salinity stress in Salvia species. Australian Crop Sci 9 (7): 656-665.

Varban DI, Duda MM, Varban R, Muntean S, Muntean L. 2010. The study of several genotypes of Echinacea purpurea (L.) Moench. Res J Agric Sci 42 (1): 319-325.

Wang D, Wang J, Zheng J, Shang Y, Li F, Yang R, Zhang C, Lu Y, Yu X. 2021. $\mathrm{Ca}^{2+}$ and $\mathrm{ABA}$ on the accumulation of GABA and flavonoids in germinated Salicornia bigelovii Torr. under $\mathrm{NaCl}$ stress. J Food Nutr Res 9 (5): 263-273. DOI: 10.12691/jfnr-9-5-4.

Yang SL, Lan SS, Deng FF, Gong M. 2016. Effects of calcium and calmodulin antagonists on chilling stress-induced proline accumulation in Jatropha curcas L. J Plant Growth Regul 35: 815826. DOI: $10.1007 / \mathrm{s} 00344-016-9584-3$.

Yavari A, Shokrpour M, Tabrizi L, Hadian J. 2017. Analysis of morphological variation and general combining ability in half sib families of Ehinacea purpurea L. Iranian J Hortic Sci 47 (4): 617 630. DOI: 10.22059/ijhs.2017.119292.723.

Zhang Q, Yang W, Liu J, Liu H, Lv Z, Zhang C, Chen D, Jiao Z. 2021. Postharvest UV-C irradiation increased the flavonoids and anthocyanins accumulation, phenylpropanoid pathway gene expression, and antioxidant activity in sweet cherries (Prunus avium L.). Postharvest Biol Technol 175: 1-10. DOI: 10.1016/j.postharvbio.2021.111490.

Zohra M, Fawzia A. 2014. Hemolytic activity of different herbal extracts used in Algeria. Int J Pharm Sci Res 5(8): 495-500. 